\title{
Composite coatings prepared by combined plasma electrolytic oxidation and chemical conversion routes on magnesium-lithium alloy
}

\author{
Zhijun $\mathrm{Li}^{\mathrm{c}}$, Yi Yuan ${ }^{\mathrm{a}}$, Xiaoyan Jing ${ }^{\mathrm{b}}$
}

\section{Abstract}

Various strategies for the elimination of inherent defects from plasma electrolytic oxidation (PEO) coatings are being developed for practical applications. In this regard, two types of composite coatings were introduced via PEO treatment followed by chemical conversion approach on a magnesium-lithium alloy ( $\mathrm{Mg}-\mathrm{Li}$ alloy). Detailed morphologies and compositions of the composite coatings were studied by scanning electron microscopy (SEM), energy-dispersive X-ray spectroscopy (EDX), X-ray photoelectron spectroscopy (XPS), and thin-film X-ray diffraction (TF-XRD). Barrier properties of the composite coatings were evaluated by potentiodynamic polarization and electrochemical impedance spectroscopy (EIS). The results demonstrate that this two-step approach improves the anti-corrosion performance of the composite coatings for protection of the $\mathrm{Mg}-\mathrm{Li}$ alloy. Specifically, the stannate composite coating exhibits enhanced corrosion resistance and impressive long-term stability relative to the composite coating prepared in cerium and lanthanum conversion solution. Our method allows the simple, 
efficient, and cost-effective fabrication of high-quality composite coatings based on a combined PEO and chemical conversion process on $\mathrm{Mg}-\mathrm{Li}$ alloys, and therefore it holds great promise for a wide range of applications where corrosion resistance is vital.

Keywords: Magnesium-lithium alloy; Composite coating; Plasma electrolytic oxidation; Chemical conversion; Corrosion resistance; Electrochemical impedance spectroscopy

\section{Introduction}

Magnesium-lithium (Mg-Li) alloys have become one of the most desirable light-weight structural materials due to their fascinating features such as high strength-to-weight ratio, high specific stiffness, excellent magnetic screen and shock resistance [1-3]. However, the poor corrosion resistance of the $\mathrm{Mg}-$ Li alloys that stems from intrinsic high chemical reactivity of magnesium and lithium has greatly impeded their potential applications and remains a major limitation [1,2]. Recently, considerable efforts of experimental studies have been sought to address this difficult challenge, such as ultrasonic-assisted electroless plating coatings [3], phosphate conversion coatings [4], molybdate/permanganate conversion coatings [5], stannate conversion coatings [6], lanthanum conversion coatings [7], epoxy coatings [8], atomic layer deposition films [9], and superhydrophobic coatings [10]. These coatings, however, either suffer from limited corrosion resistance or durability, thus affecting the overall performance of $\mathrm{Mg}-\mathrm{Li}$ alloys. In this regard, a highly effective, simple, and environmentally friendly fabrication method to improve the corrosion protection performance of coatings on $\mathrm{Mg}-\mathrm{Li}$ alloys would be advantageous for 
real-life applications.

Of the alternative methods for metal protection, plasma electrolytic oxidation (PEO) has emerged as a unique and scalable technique to produce ceramic coatings on various metal surfaces, especially magnesium and magnesium alloys, with enhanced corrosion resistance, mechanical strength, and adhesion compared to other methods [11-16]. Generally, three processes occur simultaneously during the preparation of PEO coatings, being electrochemical reactions, plasma chemical reactions, and thermal diffusion [14-16]. The inherent defects (micropores and microcracks) are formed since they act as discharge channels to release the thermal stress during the rapid solidification of molten oxides, leading to the formation of porous oxide coatings $[14,15]$. In particular, fundamental studies shown that the properties of PEO coatings are strongly related to the nature of alloy, composition and temperature of electrolyte, and electrical parameters [15-20]. Nevertheless, it remains a substantial challenge to effectively minimize these defects in PEO coatings [14,16,17].

Against this backdrop, there have been notable advances in composite coatings produced by a combination of PEO and other techniques and demonstrated enhanced mechanical and/or anti-corrosion properties relative to PEO coating alone [21-28]. Chemical conversion treatment has been widely employed in metal processing industry, as they are one of the most effective approaches to improve the anti-corrosion performance of magnesium alloys [4-7,29]. However, most chemical conversion films were deposited directly on the matrix of alloys, which tend to flake off and expose the substrate to corrosive environments. Thus far, little attention has been paid to combine chemical conversion with other methods in coating technology. Therefore, it is interesting to explore the feasibility and corrosion protection performance of the chemical conversion films deposited on PEO coatings of $\mathrm{Mg}-\mathrm{Li}$ alloys. 
Herein, we report a feasible route using a combination of PEO technique and chemical conversion method to prepare yellow plasma electrolytic oxidation/cerium and lanthanum conversion composite coating (composite coating A) and white plasma electrolytic oxidation/stannate conversion composite coating (composite coating $\mathrm{B}$ ) on a $\mathrm{Mg}-\mathrm{Li}$ alloy. The general idea is the construction of a composite coating with less defects, such as cracks and pores, which would potentially combine the advantages of corrosion protection properties of the PEO coatings and chemical conversion films, thus giving rise to improved anti-corrosion performance. Scanning electron microscopy (SEM), energy-dispersive X-ray spectroscopy (EDX), X-ray photoelectron spectroscopy (XPS), and thin-film X-ray diffraction (TFXRD) were employed to characterize morphologies and compositions of the composite coatings. Corrosion behaviors of the composite coatings were studied by potentiodynamic polarization and electrochemical impedance spectroscopy (EIS). Our study demonstrates that the composite coating prepared in stannate solution has proven to be effective as an anti-corrosion barrier, displaying markedly enhanced corrosion resistance and significant long-term stability under corrosive conditions. Overall, this approach points out a potential route for fabrication of composite coatings on $\mathrm{Mg}-\mathrm{Li}$ alloys with desirable corrosion resistance.

\section{Experimental section}

\section{1 Preparation of PEO coatings}

Cylindrical samples (height: $16 \mathrm{~mm}$, diameter: $15 \mathrm{~mm}$ ) of $\mathrm{Mg}-\mathrm{Li}$ alloy (5.6 wt.\% Li, 3.37 wt.\% Al, 1.68 wt.\% Zn, 1.14 wt.\% Ce, and Mg balance) were used for PEO treatment. The samples were first ground and polished with 800,1000 , and 2000 grit silicon carbide paper to obtain a smooth surface, then 
ultrasonically cleaned in acetone, rinsed with ethanol, and dried in air. Alkaline silicate electrolyte was prepared from a solution of $\mathrm{Na}_{2} \mathrm{SiO}_{3}(10.0 \mathrm{~g} / \mathrm{L})$ in distilled water with addition of $\mathrm{NaOH}(3.0 \mathrm{~g} / \mathrm{L})$ and triethanolamine $(10 \mathrm{ml} / \mathrm{L})$.

A direct current pulsed electrical source was employed to control the voltage, current density, and other electrical parameters. $\mathrm{Mg}-\mathrm{Li}$ alloy and a stainless-steel container were used as anode and cathode. A cooling system was used to keep the electrolyte at room temperature. The appropriate electrical parameters were as following: frequency: $2000 \mathrm{~Hz}$, duty cycle: $15 \%$, current density: $5 \mathrm{~A} / \mathrm{dm}^{2}$. After a 10-min PEO treatment, the resultant samples were rinsed thoroughly with distilled water and dried in air.

\subsection{Preparation of composite coatings}

The PEO treated sample was immersed in a chemical conversion solution $\left(2 \mathrm{~g} / \mathrm{l} \mathrm{Ce}\left(\mathrm{NO}_{3}\right)_{3}, 2 \mathrm{~g} / \mathrm{l}\right.$ $\left.\mathrm{La}\left(\mathrm{NO}_{3}\right)_{3}, 10 \mathrm{ml} / 1 \mathrm{H}_{2} \mathrm{O}_{2}\right)$ at $\mathrm{pH} 5.0$ for $1 \mathrm{~h}$ at $50{ }^{\circ} \mathrm{C}$ to obtain plasma electrolytic oxidation/cerium and lanthanum conversion composite coating (composite coating A). As for plasma electrolytic oxidation/stannate conversion composite coating (composite coating B), the PEO coating was immersed into a stannate bath $\left(20 \mathrm{~g} / \mathrm{l} \mathrm{Na}_{2} \mathrm{SnO}_{3}, 4 \mathrm{~g} / \mathrm{l} \mathrm{NaF}, 3 \mathrm{~g} / \mathrm{l} \mathrm{NaOH}\right)$ at $\mathrm{pH} 12.5$ for $1 \mathrm{~h}$ at $60{ }^{\circ} \mathrm{C}$. The resultant samples were rinsed with distilled water and dried in air. Three samples were made under each condition to ensure the reliability of experiments.

\subsection{Coating Characterization}

Morphologies and elemental compositions of composite coatings were examined using a Hitachi S4800 Field-emission scanning electron microscopy (FE-SEM) and a JSM-6480A SEM equipped with energy-dispersive X-ray spectroscopy (EDX). The thickness of the samples was measured by an eddy 
current coating thickness measurement gauge (TT 230, Time Group Inc, China). The thickness given were an average of ten measurements made at different locations. X-ray photoelectron spectroscopy (XPS) was carried out on a ESCALAB-MKII X-ray photoelectron spectrometer (VG Instruments, UK) using monochromatized Al $K_{\alpha}$ radiation (photon energy $1486.6 \mathrm{eV}$ ) as the excitation source and the binding energy of $\mathrm{C} 1 s(284.6 \mathrm{eV})$ as the reference. Xpspeak 4.1 software was used to analyze the data. Phase compositions of the samples were analyzed by a thin-film X-ray diffraction (TF-XRD, Philip X'Pert, Holland), using a $\mathrm{Cu} K_{\alpha}$ radiation as the excitation source at a grazing angle of $1^{\circ}$ with a continuous scanning mode at a rate of $3^{\circ} \min ^{-1}$. Electrochemical measurements were performed on an Im6ex electrochemical workstation (Zahner Co., Ltd) in $3.5 \mathrm{wt} . \% \mathrm{NaCl}$ solution at room temperature. Three-electrode cell was set up with a saturated calomel electrode (SCE) as the reference electrode, a platinum plate as the counter electrode, a $\mathrm{Mg}-\mathrm{Li}$ alloy or a coated sample was used as the working electrode with an exposed area of $1 \mathrm{~cm}^{2}$. Potentiodynamic polarization test was performed over a potential range of -1.8 to $-1.0 \mathrm{~V}$ at a scan rate of $2.5 \mathrm{mV} / \mathrm{s}$ after an initial $10 \mathrm{~min}$ delay. EIS measurement was conducted at open circuit potential in the frequency range from $100 \mathrm{kHz}$ to $100 \mathrm{mHz}$ with an AC amplitude of $10 \mathrm{mV}$ after a 10-min initial delay in the electrolyte to stabilize the open circuit potential. ZsimpWin 3.2 software was used to fit the impedance data. Immersion tests were performed with an $\mathrm{AC}$ amplitude of $10 \mathrm{mV}$ over the open circuit potential in the frequency range from $100 \mathrm{kHz}$ to $100 \mathrm{mHz}$ after immersion periods of 10, 25, 50,100,150, 200,250,300, and $400 \mathrm{~h}$. All electrochemical tests were conducted in triplicate in order to ensure the reproducibility of the results.

\section{Results and discussion}




\subsection{Composition analysis of the composite coatings}

Previously we have studied the anti-corrosion performance of plasma electrolyte oxide (PEO) coatings on $\mathrm{Mg}-\mathrm{Li}$ alloys, which is strongly dependent on their uniformity, porosity, thickness, and other factors [17,18]. Typically, micropores and microcracks were irregularly presented on the PEO coating surface, giving rise to the limited corrosion protection to the underlying substrate $[16,17]$. In the present work, we prepared two coatings on a Mg-Li alloy: composite coating A (yellow), produced by PEO treatment followed by cerium/lanthanum conversion method; and composite coating B (white), produced by PEO treatment followed by immersion in stannate solution.

Chemical compositions of the composite coatings were evaluated by X-ray photoelectron spectroscopy (XPS). Fig. 1 shows the XPS spectra of the composite coating A, which is mainly composed of $\mathrm{Mg}, \mathrm{Si}, \mathrm{O}, \mathrm{Ce}$, and $\mathrm{La}$. The $\mathrm{Mg} 2 p$ (Fig. 1b) spectrum reveals two components of $\mathrm{MgO}$ (50.1 eV) and $\mathrm{Mg}_{2} \mathrm{SiO}_{4}(52.2 \mathrm{eV})$ [30]. Compared with the PEO coating [27], the peak intensities of the $\mathrm{MgO}$ and $\mathrm{Mg}_{2} \mathrm{SiO}_{4}$ decreased obviously because of the formation of a chemical conversion film on the PEO coating surface. Fig. 1c shows Ce $3 d 5 / 2$ and Ce $3 d 3 / 2$ peaks, which arises from a transition from $4 \mathrm{f}^{0}$ initial state to $4 \mathrm{f}^{0}$ final state as reported elsewhere [31]. The Ce $3 d$ peaks at 908.5, 900.7, and 887.9 $\mathrm{eV}$ are assigned to $\mathrm{Ce}^{4+}$, whereas $903.5 \mathrm{eV}$ and $884.8 \mathrm{eV}$ are associated with $\mathrm{Ce}^{3+}$, implying the conversion film consists of a mixture of $\mathrm{CeO}_{2}$ and $\mathrm{Ce}_{2} \mathrm{O}_{3}[32,33]$. The $\mathrm{La} 3 d 5 / 2$ has one stable oxidation state of $\mathrm{La}^{3+}$ at $835.0 \mathrm{eV}$ (Fig. 1d), which can be attributed to $\mathrm{La}_{2} \mathrm{O}_{3}$ [34]. The $\mathrm{O} 1 s$ spectrum (Fig. 1e) consists of six components: $\mathrm{Mg}_{2} \mathrm{SiO}_{4}$ at $532.5 \mathrm{eV}$ [35], $\mathrm{MgO}$ at $531.8 \mathrm{eV}$ [36], $\mathrm{Mg}(\mathrm{OH})_{2}$ at $531.0 \mathrm{eV}$ 
[37], $\mathrm{Ce}_{2} \mathrm{O}_{3}$ at $530.2 \mathrm{eV}$ [38], $\mathrm{CeO}_{2}$ at $529.2 \mathrm{eV}$ [39], and $\mathrm{La}_{2} \mathrm{O}_{3}$ at $528.3 \mathrm{eV}$ [40]. The XPS result suggests the formation of cerium and lanthanum conversion film on the PEO coating surface.

As for the composite coating B, the Si $2 p$ spectrum (Fig. 2b) can be assigned to $\mathrm{Mg}_{2} \mathrm{SiO}_{4}(102.2 \mathrm{eV})$ [30]. The Sn $3 d$ spectrum (Fig. 2c) is split in two components at $495.5 \mathrm{eV}$ for $\mathrm{Sn} 3 d 3 / 2$ and $487.0 \mathrm{eV}$ for $\mathrm{Sn} 3 d 5 / 2$, with the corresponding peak separation $(8.5 \mathrm{eV})$ in good agreement with the literature $[41,42]$. The $\mathrm{O} 1 s$ spectrum (Fig. 2d) deconvolutes into four components: $\mathrm{MgSnO}_{3}$ at $533.2 \mathrm{eV}, \mathrm{Mg}_{2} \mathrm{SiO}_{4}$ at $532.2 \mathrm{eV}$ [35], $\mathrm{MgO}$ and $\mathrm{Mg}(\mathrm{OH})_{2}$ at $531.3 \mathrm{eV}$ [36,37]. The $\mathrm{F} 1 s$ spetrum (Fig. 2e) at $685.8 \mathrm{eV}$ corresponds to $\mathrm{MgF}_{2}$ and $\mathrm{NaMgF}_{3}$ [43]. The XPS result indicates the stannate conversion film was formed on the PEO coating.

Thin-film X-ray diffraction (TF-XRD) patterns of the $\mathrm{Mg}-\mathrm{Li}$ alloy, PEO coating, and composite coatings are shown in Fig. 3. The $\mathrm{Mg}-\mathrm{Li}$ alloy is composed of $\mathrm{Mg}$ and intermetallic compounds of $\mathrm{Al}_{2} \mathrm{Ce}$ and $\mathrm{MgZn}_{2}$. The $\mathrm{PEO}$ coating consists of $\mathrm{Mg}, \mathrm{MgO}$, and $\mathrm{Mg}_{2} \mathrm{SiO}_{4}$, which are dependent on alloy elements and electrolyte composition [15]. Following the chemical conversion treatments, the $\mathrm{Mg}, \mathrm{MgO}$, and $\mathrm{Mg}_{2} \mathrm{SiO}_{4}$ peaks for the two composite coatings are still evident in the TF-XRD patterns but with reduced peak intensities. In addition, $\mathrm{NaMgF}_{3}, \mathrm{MgF}_{2}$ and $\mathrm{MgSnO}_{3}$ peaks are clearly observed for the composite coating B. Despite the presence of Ce and La in composite coating A detected by XPS, these elements were not detectable by TF-XRD, which might result from the amorphous Ce and La compounds.

\subsection{Formation mechanism of two composite coatings}

Cerium and lanthanum are commonly used in chemical conversion methods [7,32,33]. For composite 
coating A, an addition of oxidant, $\mathrm{H}_{2} \mathrm{O}_{2}$, would favor an oxidation reaction process. The reduction of oxygen in conversion bath is as follows [32]:

$\mathrm{O}_{2}(\mathrm{~g})+2 \mathrm{H}^{+}(\mathrm{aq})+\mathrm{e}^{-} \rightarrow 2 \mathrm{OH}^{-}(\mathrm{aq})$

The formation of $\mathrm{OH}^{-}$results in an increase in the $\mathrm{pH}$ at the interface between the PEO coating and solution. The $\mathrm{OH}^{-}$preferentially combines with $\mathrm{Ce}^{3+}$ and $\mathrm{La}^{3+}$ to form $\mathrm{Ce}(\mathrm{OH})_{3}$ and $\mathrm{La}(\mathrm{OH})_{3}$, as the solubility of these precipitates $\left(K_{\mathrm{sp}, \mathrm{Ce}(\mathrm{OH})_{3}}=1.6 \times 10^{-20}, K_{\mathrm{sp}, \mathrm{La}(\mathrm{OH})_{3}}=2.0 \times 10^{-21}\right)$ is much lower than that of $\mathrm{Mg}(\mathrm{OH})_{2}\left(K_{\mathrm{sp}, \mathrm{Mg}(\mathrm{OH})_{2}}=5.6 \times 10^{-12}\right)$.

Subsequently, $\mathrm{Ce}(\mathrm{OH})_{3}$ dehydrates to oxides (eq 2). Meanwhile, $\mathrm{H}_{2} \mathrm{O}$ and $\mathrm{O}_{2}$ partially react with $\mathrm{Ce}(\mathrm{OH})_{3}$ to form $\mathrm{Ce}(\mathrm{OH})_{4}$ [32]. Thereafter, $\mathrm{Ce}(\mathrm{OH})_{4}$ dehydrates to form insoluble $\mathrm{Ce}(\mathrm{IV})$ oxide $\mathrm{CeO}_{2}$ $[32,44]$, whereas $\mathrm{La}(\mathrm{OH})_{3}$ dehydrates to form $\mathrm{La}_{2} \mathrm{O}_{3}[40]$ :

$\mathrm{Ce}(\mathrm{OH})_{3}(\mathrm{~s}) \rightarrow \mathrm{Ce}_{2} \mathrm{O}_{3}(\mathrm{~s})+6 \mathrm{H}^{+}(\mathrm{aq})$

$4 \mathrm{Ce}(\mathrm{OH})_{3}(\mathrm{~s})+\mathrm{O}_{2}(\mathrm{~g})+2 \mathrm{H}_{2} \mathrm{O}(\mathrm{aq}) \rightarrow 4 \mathrm{Ce}(\mathrm{OH})_{4}(\mathrm{~s})$

$\mathrm{Ce}(\mathrm{OH})_{4}(\mathrm{~s}) \rightarrow \mathrm{CeO}_{2}(\mathrm{~s})+2 \mathrm{H}_{2} \mathrm{O}(\mathrm{aq})$

$2 \mathrm{La}(\mathrm{OH})_{3}(\mathrm{~s}) \rightarrow \mathrm{La}_{2} \mathrm{O}_{3}(\mathrm{~s})+3 \mathrm{H}_{2} \mathrm{O}(\mathrm{aq})$

The stannate chemical conversion method is typically effective in alkaline solution $(\mathrm{pH}>12)$ for $\mathrm{Mg}$ alloys $[6,45]$. Numerous micropores and microcracks of the PEO coating are likely to be favorable for nucleation and growth of the stannate conversion film. $\mathrm{F}^{-}$acts as an accelerator and filmogen to react with $\mathrm{Mg}^{2+}$ and $\mathrm{Na}^{+}$to form $\mathrm{MgF}_{2}[45,46]$ and $\mathrm{NaMgF}_{3}[26] . \mathrm{SnO}_{3}{ }^{2-}$ reacts with $\mathrm{Mg}^{2+}$ to form insoluble $\mathrm{MgSnO}_{3}$ [45]:

$$
\begin{aligned}
& \mathrm{Mg}^{2+}(\mathrm{aq})+2 \mathrm{~F}^{-}(\mathrm{aq}) \rightarrow \mathrm{MgF}_{2}(\mathrm{~s}) \\
& \mathrm{Na}^{+}(\mathrm{aq})+\mathrm{Mg}^{2+}(\mathrm{aq})+3 \mathrm{~F}^{-}(\mathrm{aq}) \rightarrow \mathrm{NaMgF}_{3}(\mathrm{~s}) \\
& \mathrm{Mg}(\mathrm{s})+\mathrm{SnO}_{3}^{2-}(\mathrm{aq})+2 \mathrm{H}_{2} \mathrm{O}(\mathrm{aq}) \rightarrow \mathrm{MgSnO}_{3}(\mathrm{~s})+\mathrm{H}_{2}(\mathrm{~g})+2 \mathrm{OH}^{-}(\mathrm{aq})
\end{aligned}
$$


These compounds have shown corrosion resistance properties in previous studies $[7,26,32,47]$. Thus, the combined PEO and chemical conversion methods would potentially yield a composite coating with fewer defects, and effectively block the infiltration of corrosive ions reaching the $\mathrm{Mg}-\mathrm{Li}$ alloy substrate.

\subsection{Morphology characteristics of the composite coatings}

SEM images and EDX-Mapping of the composite coating A show a large amount of flake-like particles randomly distribute on the PEO coating surface (Figs. 4,5). The micropores and microcracks of the PEO coating are partially sealed by these flake-like particles, leaving few regions uncovered. The EDX-Mapping (Fig. 5) reveals that the O, La, and Ce are the most abundant elements on the coating surface, supporting the formation of a cerium and lanthanum conversion film on the surface of PEO coating.

As for the composite coating B, numerous cubic-like particles that stem from the stannate conversion treatment distribute evenly on the PEO coating surface (Figs. 6,7). A high-magnification image (Fig. 6b) depicts that these cubic-like particles have an average size of $1 \mu \mathrm{m}$ and almost fill the micropores and microcracks of the PEO coating, resulting in a relatively denser and compact composite coating. EDXMapping (Fig. 7) reveals the homogeneous distribution of these elements with high amount of $\mathrm{O}, \mathrm{Mg}, \mathrm{Si}$, low amount of $\mathrm{Sn}$, and lower amount of $\mathrm{F}$ and $\mathrm{Na}$, implying that a stannate conversion film has been deposited on the PEO coating. Furthermore, the elemental content of Sn in region 2 is 6 times higher than that in region 1 (Fig. $6 \mathrm{~b}$ and Table 1), implying the cubic-like particles are likely composed of $\mathrm{MgSnO}_{3}$. Together, the different surface phase structures on the composite coatings can be clearly distinguished. 
Cross-sectional images and the corresponding EDX analysis for both composite coatings are shown in Fig. 8. The average thicknesses of the composite coatings A and B are measured to be 22 and $18 \mu \mathrm{m}$, respectively. The elemental distribution from alloy substrate to the composite coating A surface (Fig. 8a) shows that higher amounts of $\mathrm{Ce}$ and $\mathrm{La}$ are distributed on the coating surface, in line with the EDX-Mapping result (Fig. 5). This proposed to be a result of the unfavorable incorporation of the flakelike particles into the inner dense layer of the PEO coating. In contrast, the composite coating B presents cubic-like particles attached on the walls of the micropores through both layers of PEO coating (Fig. 8b). The EDX analysis reveals that $\mathrm{F}$ is mainly distributed in the inner layer close to the alloy substrate, whereas Sn has a relatively uniform distribution along the cross-section of the oxide coating. This finding suggests that during the chemical conversion treatment, $\mathrm{F}^{-}$ions from the immersion solution favor two pathways for reaction with the $\mathrm{Mg}^{2+}$ present in the inner layer of the PEO coating: reaction with $\mathrm{Mg}^{2+}$ only to form $\mathrm{MgF}_{2}$, or with both $\mathrm{Mg}^{2+}$ and $\mathrm{Na}^{+}$to form $\mathrm{NaMgF}_{3}[26,47]$. The distribution of Sn element implies that these cubic-like particles stem from $\mathrm{MgSnO}_{3}$ distribute evenly throughout the cross-section of the PEO coating.

\subsection{Corrosion resistance evaluation}

Potentiodynamic polarization tests (Fig. 9) were carried out to determine the instantaneous corrosion rate of the samples [48]. The corresponding parameters are listed in Table 2. The decreased anodic and cathodic current densities on the coated samples relative to $\mathrm{Mg}-\mathrm{Li}$ alloy imply a decreased corrosion rate, which involves the suppression of the cathodic hydrogen evolution and anodic dissolution of the barrier layer $[12,20]$. Impressively, the composite coating B shows the lowest anodic and cathodic current densities among the 4 samples, indicating the improved corrosion protection performance 
compared to the $\mathrm{Mg}-\mathrm{Li}$ alloy, PEO coating, and composite coating A. More specifically, corrosion potential $\left(E_{\text {corr }}\right)$, corrosion current density $\left(i_{\text {corr }}\right)$, and polarization resistance $\left(R_{\mathrm{p}}\right)$ of the $\mathrm{Mg}-\mathrm{Li}$ alloy are measured to be $-1.68 \mathrm{~V} / \mathrm{SCE}, 6.46 \times 10^{-4} \mathrm{~A} / \mathrm{cm}^{2}$, and $126 \Omega \mathrm{cm}^{2}$, respectively. A smaller $i_{\text {corr }}$ and a more positive $E_{\text {corr }}$ correspond to a lower corrosion rate and a reduced corrosion tendency [1,8]. Compared to the coated samples, the $\mathrm{Mg}-\mathrm{Li}$ alloy has the most negative $E_{\text {corr }}$ and the highest $i_{\text {corr }}$, as it is the most susceptible to corrosion attack [1]. As for the PEO coating, the $E_{\text {corr }}$ shifts positively to $-1.43 \mathrm{~V} / \mathrm{SCE}$, the $i_{\text {corr }}$ decreases by two orders of magnitude $\left(2.48 \times 10^{-6} \mathrm{~A} / \mathrm{cm}^{2}\right)$, and the $R_{\mathrm{p}}$ increases by two orders of magnitude (32699 $\Omega \mathrm{cm}^{2}$ ) as compared to those of the $\mathrm{Mg}-\mathrm{Li}$ alloy.

Polarization curves of the composite coatings exhibit different characteristics relative to the PEO coating. The positive shift of corrosion potential, decreased corrosion current density, occurrence of passivation plateaus and breakdown potentials (a sharp increase in current density but a small shift in potential) were observed for both composite coatings. In contrast to the PEO coating, composite coating A shows improvement in corrosion resistance: the $E_{\text {corr }}$ further shifts $60 \mathrm{mV}$ in positive direction $(-1.37$ $\mathrm{V} / \mathrm{SCE})$, the $i_{\text {corr }}$ is approximately one order of magnitude lower $\left(8.90 \times 10^{-7} \mathrm{~A} / \mathrm{cm}^{2}\right)$, and the $R_{\mathrm{p}}$ is greater by 2.7 times $\left(86878 \Omega \mathrm{cm}^{2}\right.$ ). Impressively, the composite coating B exhibits a $E_{\text {corr }}$ of $-1.34 \mathrm{~V} / \mathrm{SCE}$, a much lower $i_{\text {corr }}$ of $2.94 \times 10^{-7} \mathrm{~A} / \mathrm{cm}^{2}$, and an impressive $R_{\mathrm{p}}$ of $137183 \Omega \mathrm{cm}^{2}$. Moreover, the anodic curve of composite coating B shows a relatively longer passivation plateau with a breakdown potential of $-1.22 \mathrm{~V} / \mathrm{SCE}$, which is $0.05 \mathrm{~V} / \mathrm{SCE}$ positive than that of the composite coating $\mathrm{A}(-1.27 \mathrm{~V} / \mathrm{SCE})$, suggesting a minimized tendency for corrosion attack. Based on the SEM, EDX, XPS, TF-XRD, and potentiodynamic polarization results, the stannate conversion film can effectively seal the porous PEO 
coating and block the infiltration of the corrosive solution to the alloy substrate, affording the excellent anti-corrosion properties.

Notably, the anti-corrosion performance of the composite coating B outperforms other coatings on Mg-Li alloys [3-7,17,18,27,49-52]. Comparing to other works [26,53-55], superior corrosion rates for coatings prepared by Shi et al. [54] and Song et al. [55] are noticed. Although the composite coating B has a similar corrosion rate compared to our previous works [26,53], it has the most positive corrosion potential among the coatings from literature [26,53-55], giving rise to the lowest tendency for corrosion. This is related to a higher coating compactness and the incorporation of thermodynamically stable compounds into the PEO coating. The significance of our present work is that an additional electrochemical test studying the performance against long-term exposure in corrosive solution was performed to analyze deeply the protection mechanism of these coatings.

Electrochemical impedance spectroscopy (EIS) was performed to gain insight into the differences in anti-corrosion performance of $\mathrm{Mg}-\mathrm{Li}$ alloy, PEO coating, and composite coatings (Fig. 10). The impedances of all coated samples are significantly greater than that of the Mg-Li alloy (Fig. 10a). The corrosion resistance of $\mathrm{Mg}-\mathrm{Li}$ alloy increases more than two orders due to the formation of PEO coating, and it further increases after the subsequent chemical conversion treatment. It is well known that the outer porous layer of PEO coating is responsible for infiltration of the corrosive solution through the oxide coating [21-25], thus the PEO coating is prone to degradation. Fig. 10b shows that the $\mathrm{Mg}-\mathrm{Li}$ alloy was characterized by a capacitive loop in high-frequency region and an inductive loop in lowfrequency region. The wave trough of the inductive loop in the low-frequency implies that the pitting corrosion occurs on the Mg-Li alloy surface. Two capacitance loops are observed for the PEO coating 
and composite coatings, indicative of the presence of two time constants for each coating. Both time constants of the composite coatings shift to a lower frequency range as compared to the PEO coating, implying a decreased tendency for corrosion [56].

In order to elucidate corrosion characteristics of these samples, equivalent circuits of $R_{\mathrm{s}}\left(Q_{\mathrm{b}} R_{\mathrm{b}}\left(L R_{\mathrm{L}}\right)\right)$ and $R_{\mathrm{s}}\left(Q_{\mathrm{ou}} R_{\mathrm{ou}}\left(Q_{\mathrm{in}} R_{\mathrm{in}}\right)\right)$ were employed to fit EIS data of the $\mathrm{Mg}-\mathrm{Li}$ alloy and coated samples (Table 3$)$ [17]. The detailed EIS study of Mg-Li alloy was reported previously [17,27]. The equivalent circuit for PEO and composite coatings consists of a solution resistance $\left(R_{\mathrm{S}}\right)$, two double layer capacitances $\left(Q_{\mathrm{ou}}\right.$ and $\left.Q_{\mathrm{in}}\right)$ and two charge transfer resistances $\left(R_{\mathrm{ou}}\right.$ and $\left.R_{\mathrm{in}}\right)$. The $R_{\mathrm{s}}$ depends on the geometry of cell and the conductivity of the solution. The $R_{\mathrm{ou}}$ and $Q_{\mathrm{ou}}$ correspond to the resistance/capacitance of the outer layer of the coated samples, while the $R_{\text {in }}$ and $Q_{\text {in }}$ are associated with those of the inner layer. Generally, the higher corrosion resistance can be ascribed to the enhanced barrier properties with fewer defects present in the coating. As for the PEO coating, the $R_{\mathrm{ou}}$ is one fourth of the $R_{\mathrm{in}}$, indicating the inner dense layer serves as the most important corrosion-resistant layer. Compared to the PEO coating, the $R_{\text {ou }}$ for composite coating A further increases from $6.02 \times 10^{3}$ to $1.54 \times 10^{4} \Omega \mathrm{cm}^{2}$, and the $R_{\text {in }}$ increases from $2.24 \times 10^{4}$ to $5.05 \times 10^{4} \Omega \mathrm{cm}^{2}$. This can be ascribed to the formation of a cerium and lanthanum conversion film on the PEO coating. As previously mentioned, such chemical conversion film only partially sealed the PEO coating, which is not favorable for long-term protection of the Mg-Li alloy. By incorporating a stannate conversion film into the PEO coating, the defects in the PEO coating were effectively sealed by the thermodynamically stable compounds $\left(\mathrm{NaMgF}_{3}, \mathrm{MgF}_{2}\right.$, and $\left.\mathrm{MgSnO}_{3}\right)$, as evidenced by the above findings, generating a densely packed composite coating. The corresponding $R_{\text {ou }}$ for composite coating B improves significantly from $1.54 \times 10^{4}$ to $3.21 \times 10^{4} \Omega \mathrm{cm}^{2}$ and $R_{\text {in }}$ increases from 
$5.05 \times 10^{4}$ to $5.68 \times 10^{4} \Omega \mathrm{cm}^{2}$ as compared to the composite coating A. Such markedly enhanced anticorrosion of the composite coating B firmly supports the hypothesis that a lower tendency to corrosion, a higher charge transfer resistance, a lower corrosion rate, and a less exposure area were involved in the corrosion reaction.

\subsection{EIS evaluation of corrosion deterioration}

The durability of coatings in corrosive environments is important for practical applications $[27,48,57]$. Thus, we have chosen the EIS to investigate the long-term durability and the associated deterioration process of the composite coatings in $3.5 \mathrm{wt} . \% \mathrm{NaCl}$ solution over a time period of $400 \mathrm{~h}$ (Fig.11).

Fig. 11a illustrates the EIS behavior of the composite coating A during different immersion periods. The high frequency and low-frequency regions are related to the properties of the outer layer and inner layer of the composite coatings. The diameters of Nyquist plots for the composite coating A decrease significantly with prolonging immersion time, illustrating the coating deteriorates seriously during the immersion. This is because the corrosive solution penetrates the flake-like chemical conversion film and PEO coating, exposing the underlying alloy to the corrosive environment. During the initial immersion stage $(10 \mathrm{~h})$, the composite coating A exhibits large capacitive loops, indicating it provides effective corrosion protection. However, the dimension of the capacitance loops shrink markedly along with an appearance of inductive loop after exposure for $25 \mathrm{~h}$, suggesting the degradation of the composite coating. With prolonging immersion time up to $400 \mathrm{~h}$, further degradation is observed due to the rapid shrinkage of the capacitance loops.

As for the composite coating B, superior corrosion resistance properties are observed throughout the course of the immersion test (Fig. 11b). Prior to the immersion, the diameter of Nyquist plots for 
composite coating $\mathrm{B}$ is larger than that of composite coating $\mathrm{A}$ and exhibits less degradation during the test, indicating far greater corrosion protection. Relatively large and stable capacitance loops are noticed during the initial $25 \mathrm{~h}$ immersion, with only a limited shrinkage of the capacitance loop observed in the high frequency range, since the initial corrosion process occurs mainly in the outer layer of the composite coating. Then the composite coating B exhibits a complex trend during the following immersion test. The impedance value decreases sharply in the 25 to $50 \mathrm{~h}$ of the immersion period, followed by small fluctuations until $150 \mathrm{~h}$, and a subsequent marked increase until $250 \mathrm{~h}$ of exposure. This enhanced corrosion resistance might result from the formation of corrosion products on the coating surface, which partially act as a barrier that inhibits the penetration of corrosive solution. Thereafter, the corrosion products dissolved into the corrosive solution, resulting in a further decrease in the coating resistance.

The impedance of Bode plots at low frequencies can be employed to evaluate corrosion protection performance of the coatings [27,48]. Fig. 12 shows the variation of corrosion resistance of composite coatings at low frequency $\left(|\mathrm{Z}|_{f=0.1 \mathrm{~Hz}}\right)$ as a function of immersion time [27]. The resistance values of two composite coatings show a similar trend during the initial $100 \mathrm{~h}$ immersion. Then the resistance value of composite coating A dropped rapidly to $790 \Omega \mathrm{cm}^{2}$ after $400 \mathrm{~h}$ immersion. This significant decrease in the corrosion resistance indicates the loss of the barrier properties and the penetration of corrosive solution to the $\mathrm{Mg}-\mathrm{Li}$ alloy. On the contrary, there was negligible loss of corrosion resistance for the composite coating B between 100 and $150 \mathrm{~h}$, followed by an increase in corrosion resistance up to $300 \mathrm{~h}$. As previously mentioned, this is likely because the corrosion products blocked the penetration of the corrosive solution. After that, the corrosion products dissolved into the corrosion solution and the 
corresponding corrosion resistance of the composite coating B decreased to $4120 \Omega \mathrm{cm}^{2}$ (400 h), which is far greater than that of the composite coating $\mathrm{A}\left(790 \Omega \mathrm{cm}^{2}\right)$. This is likely attributed to the differences in microstructures, compactness, and compositions between two composite coatings. The composite coating A was only partially sealed and the corrosion attack was more susceptible to initiate from the defects. In contrast, composite coating B possess densely packed microstructure and thermodynamically stable compounds, effectively blocked the corrosive ions from reaching the $\mathrm{Mg}-\mathrm{Li}$ alloy, giving rise to the retarded corrosion initiation and/or minimized corrosion attack.

Examination of the corroded surfaces reveals different corrosion behaviors (Fig. 13). We observe that the composite coating A was severely corroded with several large regions flaked-off, exposing the $\mathrm{Mg}-$ Li alloy to the corrosive environment. In sharp contrast, the composite coating B can continue to offer effective corrosion protection with limited/mild corrosion damages on the coating surface, confirming its superior anti-corrosion performance than that of the composite coating A.

\section{Conclusions}

In summary, we have demonstrated a feasible approach based on a combination of PEO technique and chemical conversion method to fabricate yellow composite coating A and white composite coating B on a Mg-Li alloy. SEM images of the composite coatings A and B depict numerous flake-like and cubic-like particles on the PEO coatings. The composite coating A consists of $\mathrm{Ce}_{2} \mathrm{O}_{3}, \mathrm{CeO}_{2}, \mathrm{La}_{2} \mathrm{O}_{3}, \mathrm{Mg}_{2} \mathrm{SiO}_{4}, \mathrm{MgO}$, and $\mathrm{Mg}(\mathrm{OH})_{2}$, whereas the composite coating $\mathrm{B}$ contains $\mathrm{MgSnO}_{3}, \mathrm{NaMgF}_{3}, \mathrm{MgF}_{2}, \mathrm{Mg}_{2} \mathrm{SiO}_{4}, \mathrm{MgO}$, and $\mathrm{Mg}(\mathrm{OH})_{2}$. Compared to the PEO coating, both composite coatings exhibit the enhanced resistance to corrosion attack. Importantly, incorporation of a stannate chemical conversion film with numerous thermodynamically stable compounds into the PEO coating affords a higher degree of coating 
compactness, giving rise to superior corrosion resistance and long-term stability in corrosive environments. Based on these findings, we envision that this method has potential in the development of anti-corrosion coatings for $\mathrm{Mg}-\mathrm{Li}$ alloys, and will substantially expand the application scopes of these materials.

\section{Acknowledgements}

This work was supported by the National 973 program (2015CB932204), the National Science Foundation of China (No. 91233206 and No. 51673165), and the key Technology R\&D program (BE2014147-1) Science and Technology Department of Jiangsu Province.

\section{References}

[1] Y.W. Song, D.Y. Shan, R.S. Chen, E.H. Han, Corrosion characterization of Mg-8Li alloy in NaCl solution, Corros. Sci. 51 (2009) 1087-1094.

[2] W. Xu, N. Birbilis, G. Sha, Y. Wang, J. E. Daniels, Y. Xiao, M. Ferry, A high-specific-strength and corrosionresistant magnesium alloy, Nat. Mater. 14 (2015) 1229-1236.

[3] Y. Zou, Z. Zhang, S. Liu, D. Chen, G. Wang, Y. Wang, M. Zhang, Y. Chen, Ultrasonic-assisted electroless Ni-P plating on dual phase Mg-Li alloy, J. Electrochem. Soc. 162 (2015) C64-C70.

[4] Y.W. Song, D.Y. Shan, R.S. Chen, F. Zhang, E.H. Han, Formation mechanism of phosphate conversion film on Mg-8.8Li alloy, Corros. Sci. 51 (2009) 62-69.

[5] G.X. Wang, M.L. Zhang, R.Z. Wu, Molybdate and molybdate/permanganate conversion coatings on Mg-8.5Li alloy, Appl. Surf. Sci. 258 (2012) 2648-2654. 
[6] L.H. Yang, M.L. Zhang, J.Q. Li, X. Yu, Z.Y. Niu, Stannate conversion coatings on Mg-8Li alloy, J. Alloy. Compd. 471 (2009) 197-200.

[7] D.L. Song, X.Y. Jing, J. Wang, S.S. Lu, P.P. Yang, Y.L. Wang, M.L. Zhang, Microwave-assisted synthesis of lanthanum conversion coating on Mg-Li alloy and its corrosion resistance, Corros. Sci. 53 (2011) 3651-3656.

[8] Y.W. Shao, H. Huang, T. Zhang, G.Z. Meng, F.H. Wang, Corrosion protection of Mg-5Li alloy with epoxy coatings containing polyaniline, Corros. Sci. 51 (2009) 2906-2915.

[9] P.C. Wang, Y.T. Shih, M.C. Lin, H.C. Lin, M.J. Chen, K.M. Lin, Improvement of wear and cavitation-erosion by ALD-deposited $\mathrm{LiAl}_{\mathrm{x}} \mathrm{O}_{\mathrm{y}}$ films on an Mg-10Li-0.5Zn alloy, Surf. Coat. Technol. 204 (2010) 3707-3712.

[10] K.S. Liu, M.L. Zhang, J. Zhai, J. Wang, L. Jiang, Bioinspired construction of Mg-Li alloys surfaces with stable superhydrophobicity and improved corrosion resistance, Appl. Phys. Lett. 92 (2008) 183103.

[11] Y. Chen, X. Nie, D.O. Northwood, Investigation of plasma electrolytic oxidation (PEO) coatings on a $\mathrm{Zr}-2.5 \mathrm{Nb}$ alloy using high temperature/pressure autoclave and tribological tests, Surf. Coat. Technol. 205 (2010) 1774-1782.

[12] J. Liang, P.B. Srinivasan, C. Blawert, W. Dietzel, Electrochemical corrosion behaviour of plasma electrolytic oxidation coatings on AM50 magnesium alloy formed in silicate and phosphate based electrolytes, Electrochim. Acta 54 (2009) 3842-3850.

[13] Y. Cheng, J. Cao, Z. Peng, Q. Wang, E. Matykina, P. Skeldon, G.E. Thompson, Wear-resistant coatings formed on Zircaloy-2 by plasma electrolytic oxidation in sodium aluminate electrolytes, Electrochimi. Acta 116 (2014) 453-466.

[14] Y. Mori, A. Koshi, J. Liao, Corrosion resistance of plasma electrolytic oxidation layer of a non-ignitable Mg-AlMn-Ca magnesium alloy, Corros. Sci. 104 (2016) 207-216.

[15] R.O. Hussein, X. Nie, D.O. Northwood, An investigation of ceramic coating growth mechanisms in plasma electrolytic oxidation (PEO) processing, Electrochimi. Acta 112 (2013) 111-119. 
[16] R.O. Hussein, D.O. Northwood, X. Nie, The effect of processing parameters and substrate composition on the corrosion resistance of plasma electrolytic oxidation (PEO) coated magnesium alloys, Surf. Coat. Technol. 237 (2013) $357-368$.

[17] Z.J. Li, Y. Yuan, X.Y. Jing, Effect of current density on the structure, composition and corrosion resistance of plasma electrolytic oxidation coatings on Mg-Li alloy, J. Alloy. Compd. 541 (2012) 380-391.

[18] Z.J. Li, Y. Yuan, P.P. Sun, X.Y. Jing, Ceramic coatings of LA141 alloy formed by plasma electrolytic oxidation for corrosion protection, ACS Appl. Mater. Interfaces 3 (2011) 3682-3690.

[19] Y. Cheng, Z. Peng, X. Wu, J. Cao, P. Skeldon, G.E. Thompson, A comparison of plasma electrolytic oxidation of Ti-6Al-4V and Zircaloy-2 alloys in a silicate-hexametaphosphate electrolyte, Electrochimi. Acta 165 (2015) 301-313.

[20] Y.-H. Wang, Z.-G. Liu, J.-H. Ouyang, Y.-M. Wang, Y. Zhou, Influence of electrolyte compositions on structure and high-temperature oxidation resistance of microarc oxidation coatings formed on Ti2AlNb alloy, J. Alloy. Compd. 647 (2015) 431-437.

[21] L. Wang, J. Zhou, J. Liang, J. Chen, Corrosion mechanism of plasma electrolytic oxidation coated magnesium alloy with laser surface melting pretreatment, J. Electrochem. Soc. 161 (2014) C20-C25.

[22] P. Shi, B. Niu, S.S. E, Y. Chen, Q. Li, Preparation and characterization of PLA coating and PLA/MAO composite coatings on AZ31 magnesium alloy for improvement of corrosion resistance, Surf. Coat. Technol. 262 (2014) 26-32.

[23] X.J. Cui, X.Z. Lin, C.H. Liu, R.S. Yang, X.W. Zheng, M. Gong, Fabrication and corrosion resistance of a hydrophobic micro-arc oxidation coating on AZ31 Mg alloy, Corros. Sci. 90 (2015) 402-412.

[24] H.S. Ryu, D.S. Park, S.H. Hong, Improved corrosion protection of AZ31 magnesium alloy through plasma electrolytic oxidation and aerosol deposition duplex treatment, Surf. Coat. Technol. 219 (2013) 82-87.

[25] X.H. Guo, K.Q. Du, Q.Z. Guo, Y. Wang, F.H. Wang, Experimental study of corrosion protection of a three-layer 
film on AZ31B Mg alloy, Corros. Sci. 65 (2012) 367-375.

[26] P.P. Sun, Y. Lu, Y. Yuan, X.Y. Jing, M.L. Zhang, Preparation and characterization of duplex PEO/MoC coatings on Mg-Li alloy, Surf. Coat. Technol. 205 (2011) 4500-4506.

[27] Z.J. Li, Y. Yuan, X.Y. Jing, M.L. Zhang, Composite coatings on a Mg-Li alloy prepared by combined plasma electrolytic oxidation and sol-gel techniques, Corros. Sci. 63 (2012) 358-366.

[28] R. Arrabal, J.M. Mota, A. Criado, A. Pardo, M. Mohedano, E. Matykina, Assessment of duplex coating combining plasma electrolytic oxidation and polymer layer on AZ31 magnesium alloy, Surf. Coat. Technol. 206 (2012) 46924703.

[29] S. Pommiers, J. Frayret, A. Castetbon, M. Potin-Gautier, Alternative conversion coatings to chromate for the protection of magnesium alloys, Corros. Sci. 84 (2014) 135-146.

[30] Y.Q. Wang, M.Y. Zheng, K. Wu, Microarc oxidation coating formed on SiCw/AZ91 magnesium matrix composite and its corrosion resistance, Mater. Lett. 59 (2005) 1727-1731.

[31] X. Yu, G. Li, XPS study of cerium conversion coating on the anodized 2024 aluminum alloy, J. Alloy. Compd. 364 (2004) 193-198.

[32] C. Wang, S.L. Zhu, F. Jiang, F.H. Wang, Cerium conversion coatings for AZ91D magnesium alloy in ethanol solution and its corrosion resistance, Corros. Sci. 51 (2009) 2916-2923.

[33] H. Ardelean, I. Frateur, P. Marcus, Corrosion protection of magnesium alloys by cerium, zirconium and niobiumbased conversion coatings, Corros. Sci. 50 (2008) 1907-1918.

[34] M.A. Arenas, I. García, J. de Damborenea, X-ray photoelectron spectroscopy study of the corrosion behaviour of galvanised steel implanted with rare earths, Corros. Sci. 46 (2004) 1033-1049.

[35] C.D. Wagner, D.A. Zatko, R.H. Raymond, Use of the oxygen KLL Auger lines in identification of surface 
chemical states by electron spectroscopy for chemical analysis, Anal. Chem. 52 (1980) 1445-1451.

[36] L. Kang, J. Gao, H.R. Xu, S.Q. Zhao, H. Chen, P.H. Wu, Epitaxial $\mathrm{Mg}_{2} \mathrm{SiO}_{4}$ thin films with a spinel structure grown on Si substrates, J. Cryst. Growth. 297 (2006) 100-104.

[37] D.E. Haycock, M. Kasrai, C.J. Nicholls, D.S. Urch, The electronic structure of magnesium hydroxide (brucite) using X-ray emission, X-ray photoelectron, and auger spectroscopy, J. Chem. Soc. Dalton Trans. (1978) 1791-1796.

[38] G. Praline, B.E. Koel, R.L. Hance, H.I. Lee, J.M. White, X-Ray photoelectron study of the reaction of oxygen with cerium, J. Electron Spectrosc. Relat. Phenom. 21 (1980) 17-30.

[39] D.D. Sarma, C.N.R. Rao, XPES studies of oxides of second- and third-row transition metals including rare earths, Electron Spectrosc. Relat. Phenom. 20 (1980) 25-45.

[40] W.Y. Howng, R.J. Thorn, Investigation of the electronic structure of $\mathrm{La}_{1-\mathrm{x}}\left(\mathrm{M}^{2+}\right)_{\mathrm{x}} \mathrm{CrO}_{3}, \mathrm{Cr}_{2} \mathrm{O}_{3}$ and $\mathrm{La}_{2} \mathrm{O}_{3}$ by $\mathrm{X}-$ ray photoelectron spectroscopy, J. Phys. Chem. Solids 41 (1980) 75-81.

[41] F. Montilla, E. Morallon, A. De Battisti, S. Barison, S. Daolio, J.L. Vazquez, Preparation and characterization of antimony-doped tin dioxide electrodes. 3. XPS and SIMS characterization, J. Phys. Chem. B 108 (2004) 15976-15981.

[42] P.Y. Liu, J.F. Chen, W.D. Sun, Characterizations of $\mathrm{SnO}_{2}$ and $\mathrm{SnO}_{2}: \mathrm{Sb}$ thin films prepared by PECVD, Vacuum 76 (2004) 7-11.

[43] J.K. Murthy, U. Gross, S. Rüdiger, E. Ünveren, W. Unger, E. Kemnitz, Synthesis and characterization of chromium(III)-doped magnesium fluoride catalysts, Appl. Catal. A. 282 (2005) 85-91.

[44] P. Yu, S.A. Hayes, T.J. O'Keefe, M.J. O’Keefe, J.O. Stoffer, The phase stability of cerium species in aqueous systems II. The systems. equilibrium considerations and pourbaix diagram calculations, J. Electrochem. Soc. 153 (2006) C74-C79.

[45] Y.H. Huang, Y.L. Lee, C.S. Lin, Acid pickling pretreatment and stannate conversion coating treatment of AZ91D 
magnesium alloy, J. Electrochem. Soc. 158 (2011) C310-C317.

[46] T.F. da Conceicao, N. Scharnagl, C. Blawert, W. Dietzel, K.U. Kainer, Surface modification of magnesium alloy AZ31 by hydrofluoric acid treatment and its effect on the corrosion behaviour, Thin Solid Films 518 (2010) 5209-5218.

[47] A. Yamamoto, T. Terawaki, H. Tsubakino, Microstructures and corrosion properties on fluoride treated magnesium alloy, Materials Transactions, 49 (2008) 1042-1047.

[48] X. Zhang, G. Wu, X. Peng, L. Li, H. Feng, B. Gao, K. Huo, P. K. Chu, Mitigation of corrosion on magnesium alloy by predesigned surface corrosion. Sci. Rep. 5 (2015) 17399-17409.

[49] X. Yang, G. Wang, G. Dong, F. Gong, M. Zhang, Rare earth conversion coating on Mg-8.5Li alloys, J. Alloy. Compd. 487 (2009) 64-68.

[50] Y. Song, D. Shan, R. Chen, F. Zhang, E.-H. Han, A novel phosphate conversion film on Mg-8.8Li alloy, Surf. Coat. Technol. 203 (2009) 1107-1113.

[51] L. Yang, J. Li, X. Yu, M. Zhang, X. Huang, Lanthanum-based conversion coating on Mg-8Li alloy, Appl. Surf. Sci. 255 (2008) 2338-2341.

[52] H. Zhang, G. Yao, S. Wang, Y. Liu, H. Luo, A chrome-free conversion coating for magnesium-lithium alloy by a phosphate-permanganate solution, Surf. Coat. Technol. 202 (2008) 1825-1830.

[53] J. Liu, Y. Lu, X. Jing, Y. Yuan, M. Zhang, Characterization of plasma electrolytic oxidation coatings formed on Mg-Li alloy in an alkaline silicate electrolyte containing silica sol, Mater Corros, 60 (2009) 865-870.

[54] L.L. Shi, Y.J. Xu, K. Li, Z.P. Yao, S.Q. Wu, Effect of additives on structure and corrosion resistance of ceramic coatings on Mg-Li alloy by micro-arc oxidation, Curr Appl Phys, 10 (2010) 719-723.

[55] L. Song, Y. Kou, Y. Song, D. Shan, G. Zhu, E.H. Han, Fabrication and characterization of micro-arc oxidation (MAO) coatings on Mg-Li alloy in alkaline polyphosphate electrolytes without and with the addition of K2TiF6, Mater 
Corros, 62 (2011) 1124-1132.

[56] N. Imaz, M. Ostra, M. Vidal, J.A. Díez, M. Sarret, E. García-Lecina, Corrosion behaviour of chromium coatings obtained by direct and reverse pulse plating electrodeposition in $\mathrm{NaCl}$ aqueous solution, Corros. Sci. 78 (2014) 251259.

[57] A.E. Hughes, I.S. Cole, T.H. Muster, R.J. Varley, Designing green, self-healing coatings for metal protection, NPG Asia Mater. 2 (2010) 143-151. 


\section{Figure captions}

Fig. 1 XPS spectra of composite coating A. (a) the survey spectrum, the specific spectra of (b) $\mathrm{Mg} 2 p$, (c) Ce $3 d$, (d) La $3 d$, and (e) O $1 s$.

Fig. 2 XPS spectra of composite coating B. (a) the survey spectrum, the specific spectra of (b) Si $2 p$, (c) Sn $3 d$, (d) O $1 s$, and (e) F $1 s$.

Fig. 3 TF-XRD patterns of (a) Mg-Li alloy, (b) PEO coating, (c) composite coating A, and (d) composite coating B.

Fig. 4 FE-SEM image of (a) low-magnification and (b) high-magnification of composite coating A.

Fig. 5 EDX-Mapping of composite coating A.

Fig. 6 FE-SEM images of (a) low-magnification and (b) high-magnification of composite coating B.

Fig. 7 EDX-Mapping of composite coating B.

Fig. 8 FE-SEM images and the corresponding elements distribution along the distance from substrate/coating interface of (a) composite coating A and (b) composite coating B.

Fig. 9 Potentiodynamic polarization curves of (a) $\mathrm{Mg}-\mathrm{Li}$ alloy, (b) PEO coating, (c) composite coating $\mathrm{A}$, and (d) composite coating B.

Fig. 10 Electrochemical impedance spectroscopy of (1) Mg-Li alloy, (2) PEO coating, (3) composite coating A, and (4) composite coating B. (a) $|\mathrm{Z}|$ vs. frequency; (b) Phase angles vs. frequency.

Fig. 11 Electrochemical impedance behaviors of (a) composite coating A and (b) composite coating B at different immersion time in $3.5 \mathrm{wt} . \% \mathrm{NaCl}$ solution.

Fig. 12 Corrosion resistance as a function of immersion time of (a) composite coating A and (b) composite coating B in 3.5 wt. $\% \mathrm{NaCl}$ solution.

Fig. 13 Photographs of (a) composite coating A and (b) composite coating B after $400 \mathrm{~h}$ immersion in $3.5 \mathrm{wt} \% \mathrm{NaCl}$ solution. 

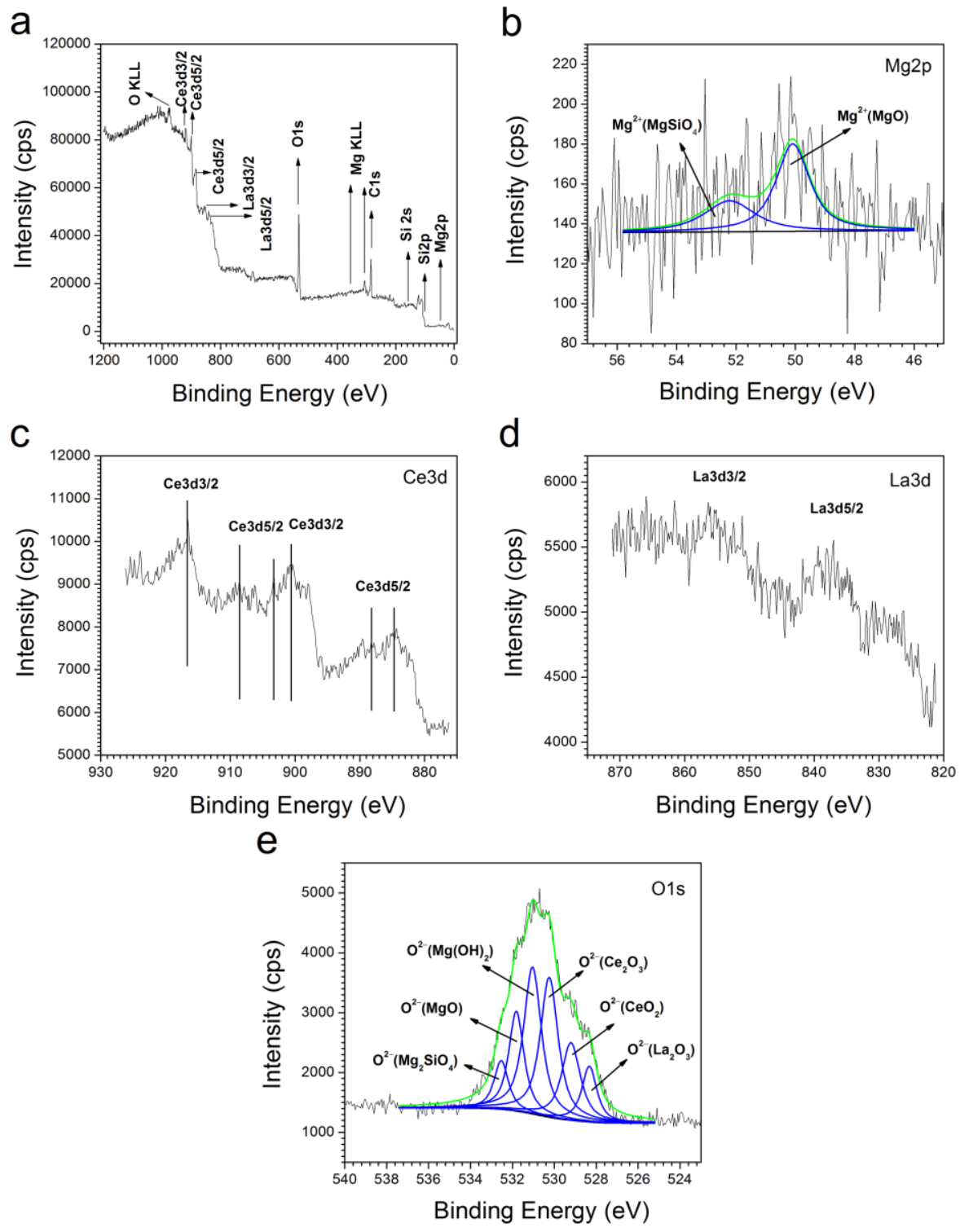

Fig. 1 
a
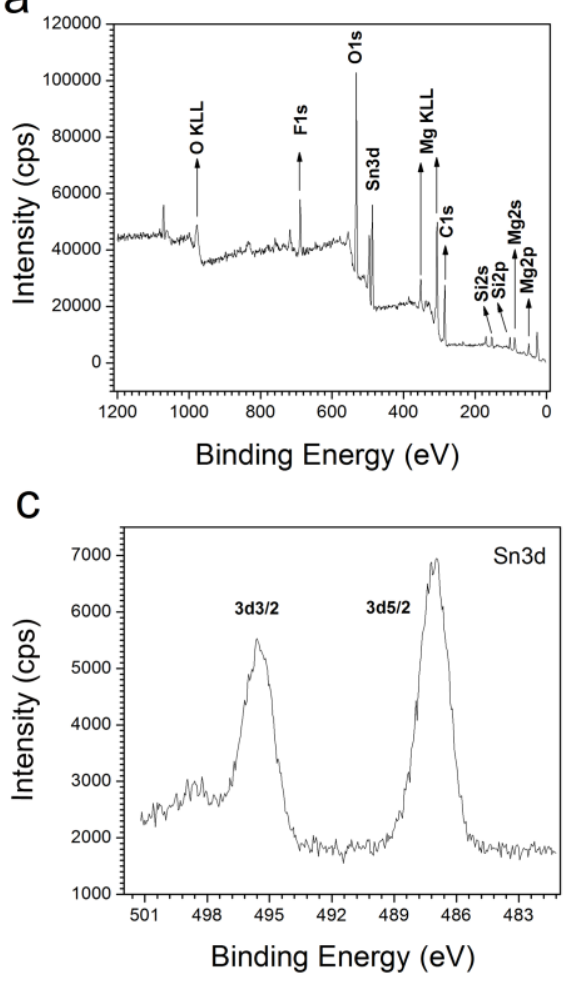

b

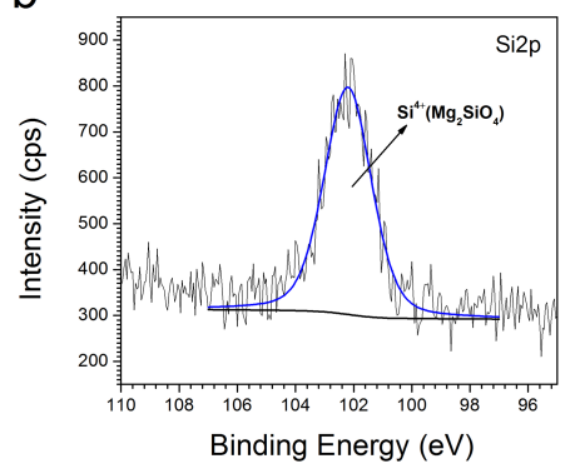

d

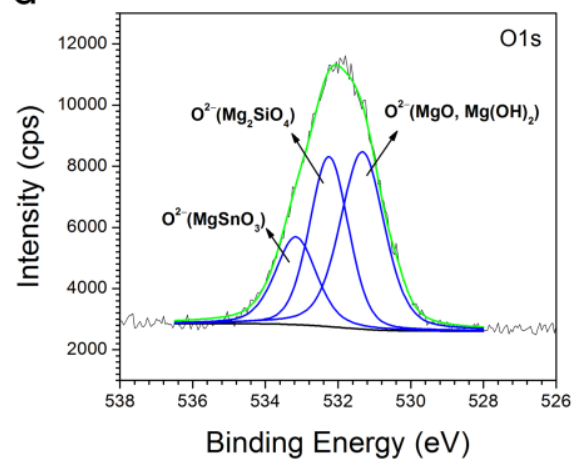

e

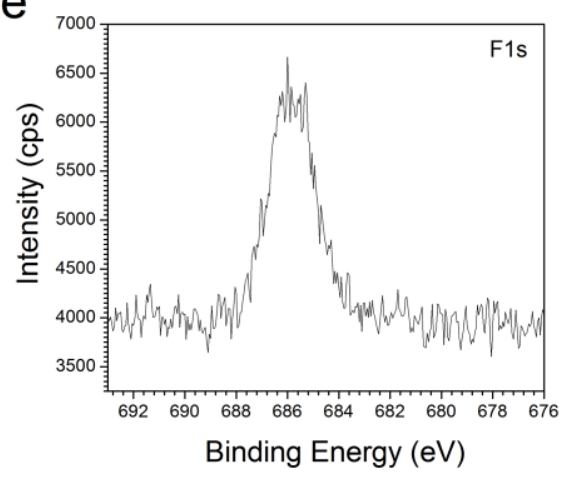

Fig. 2 


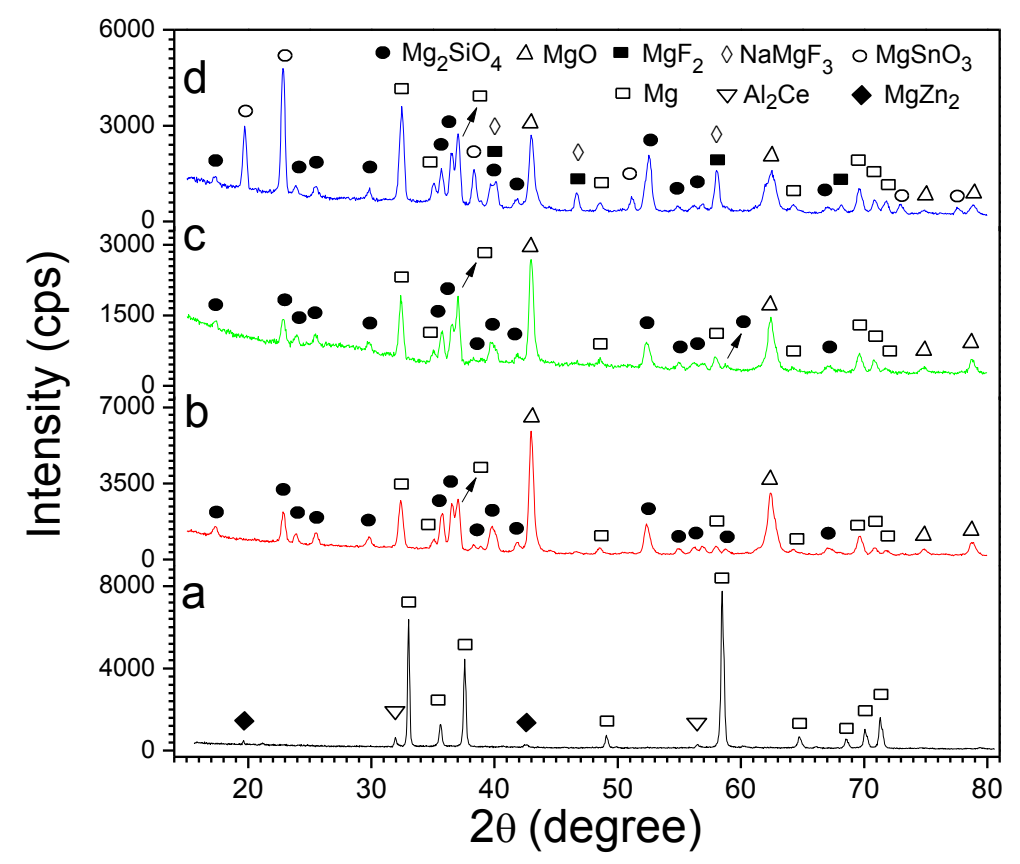

Fig. 3 


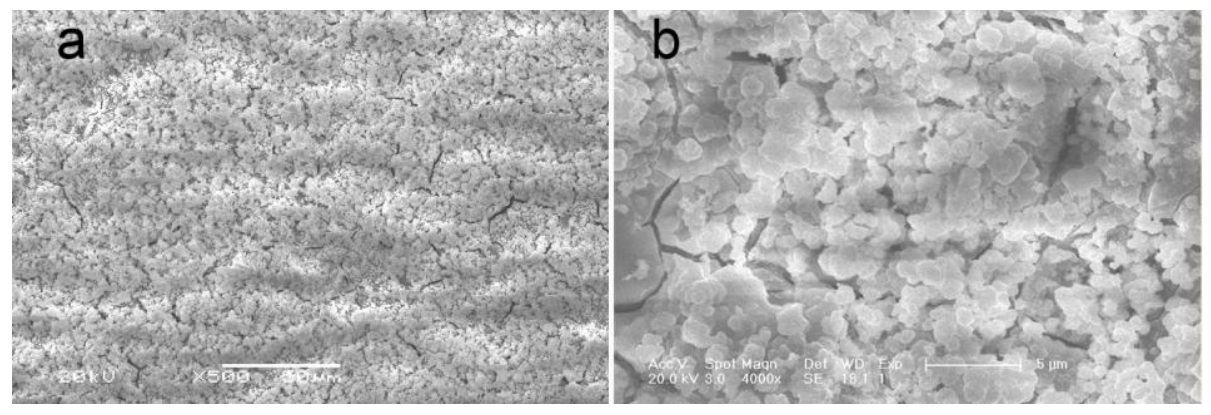

Fig. 4 


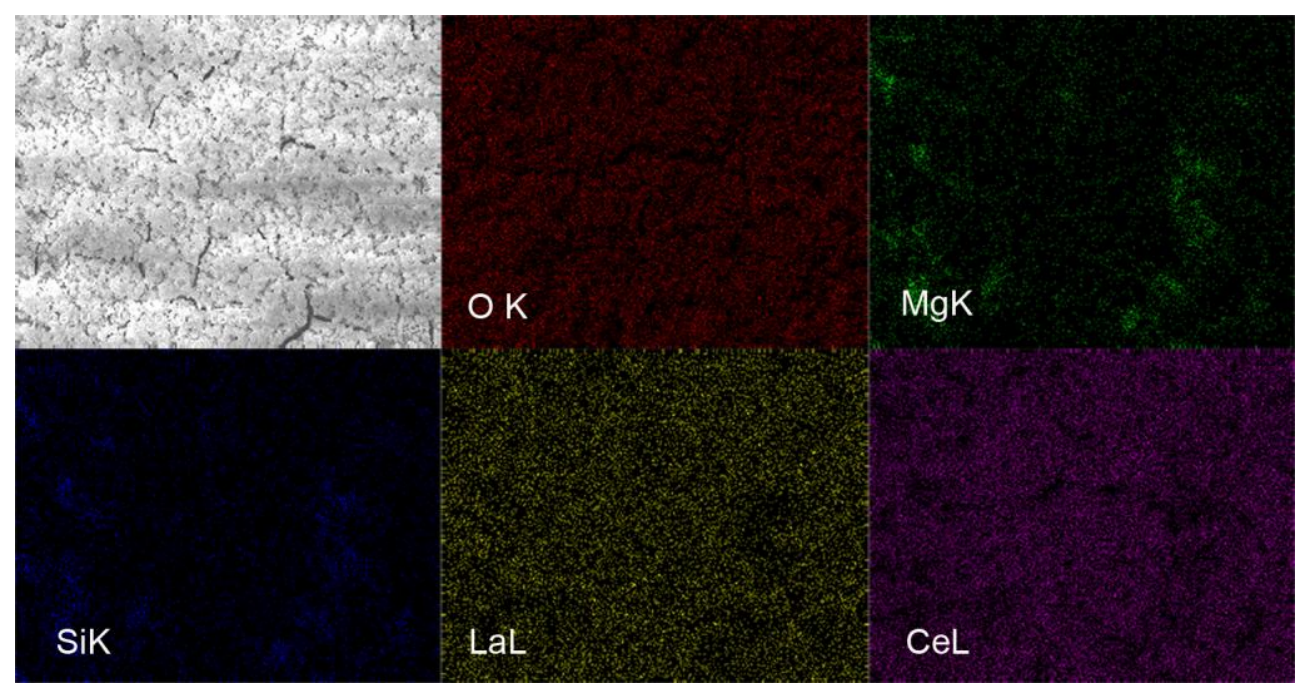

Fig. 5 


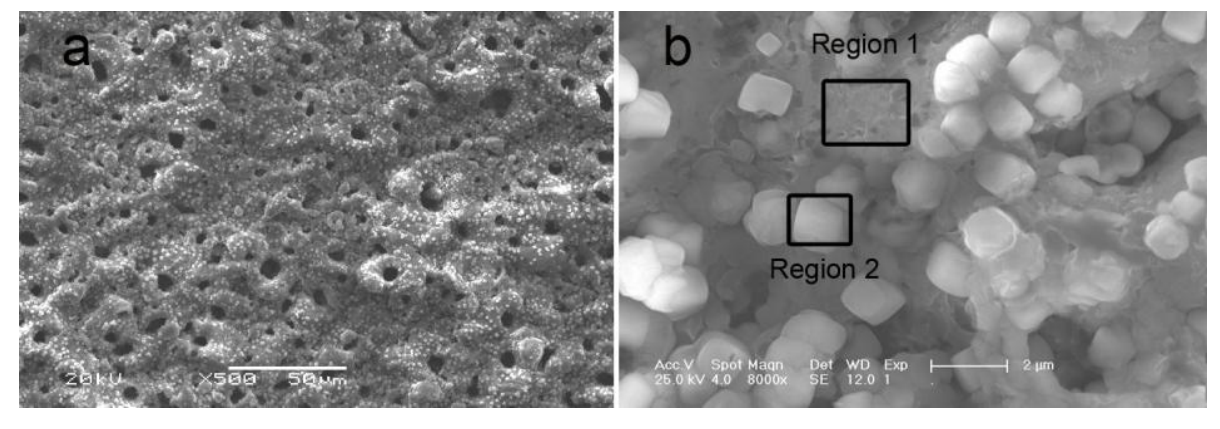

Fig. 6 


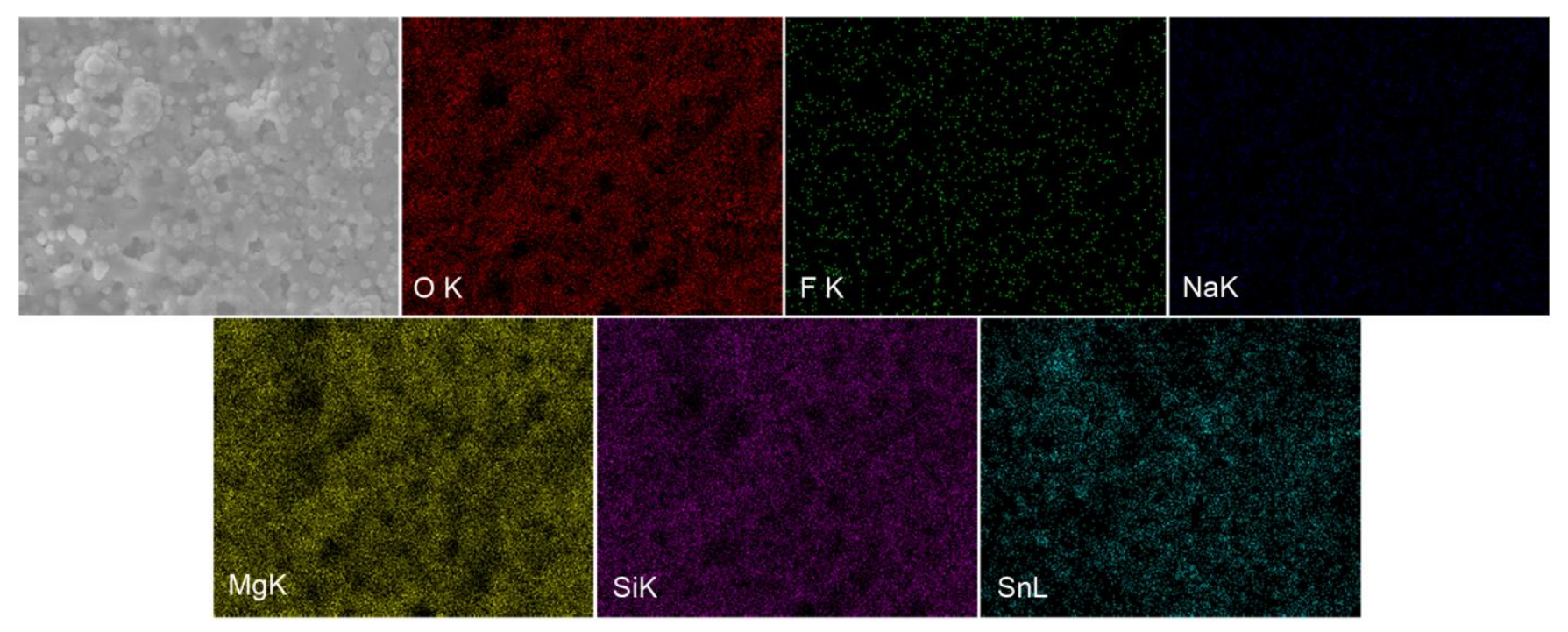

Fig. 7 

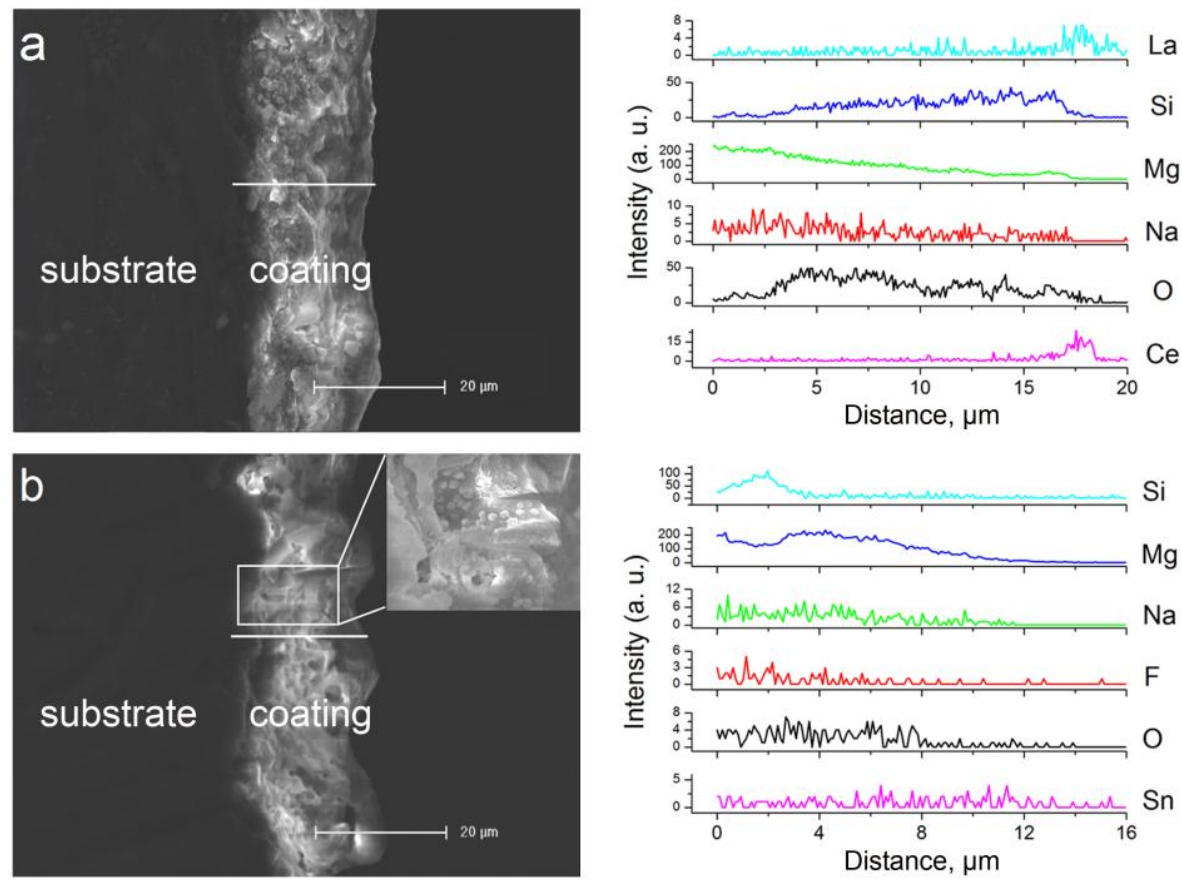

Fig. 8 


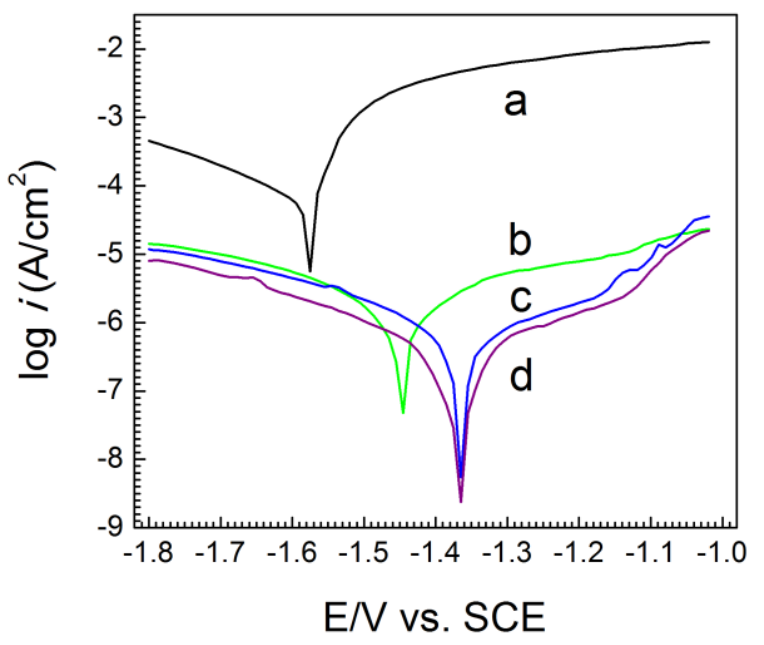

Fig. 9 

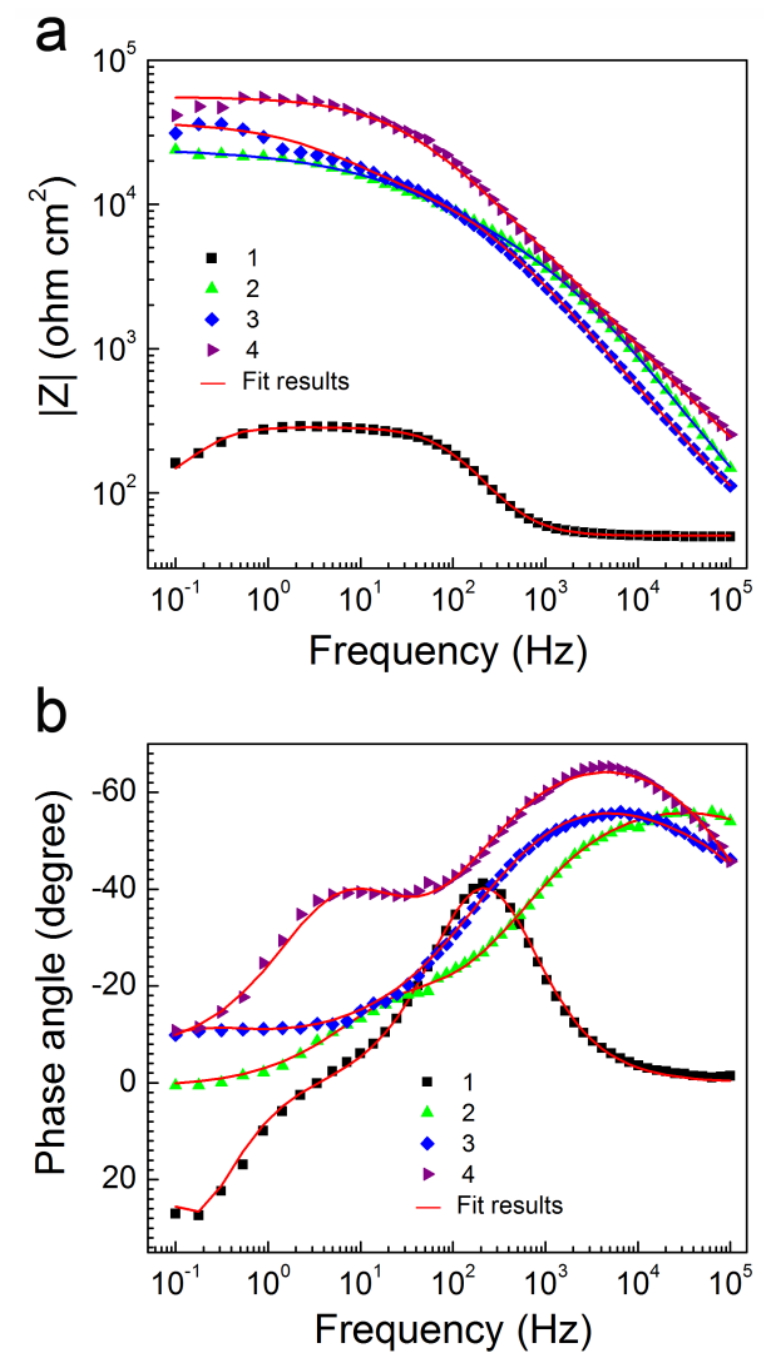

Fig. 10 

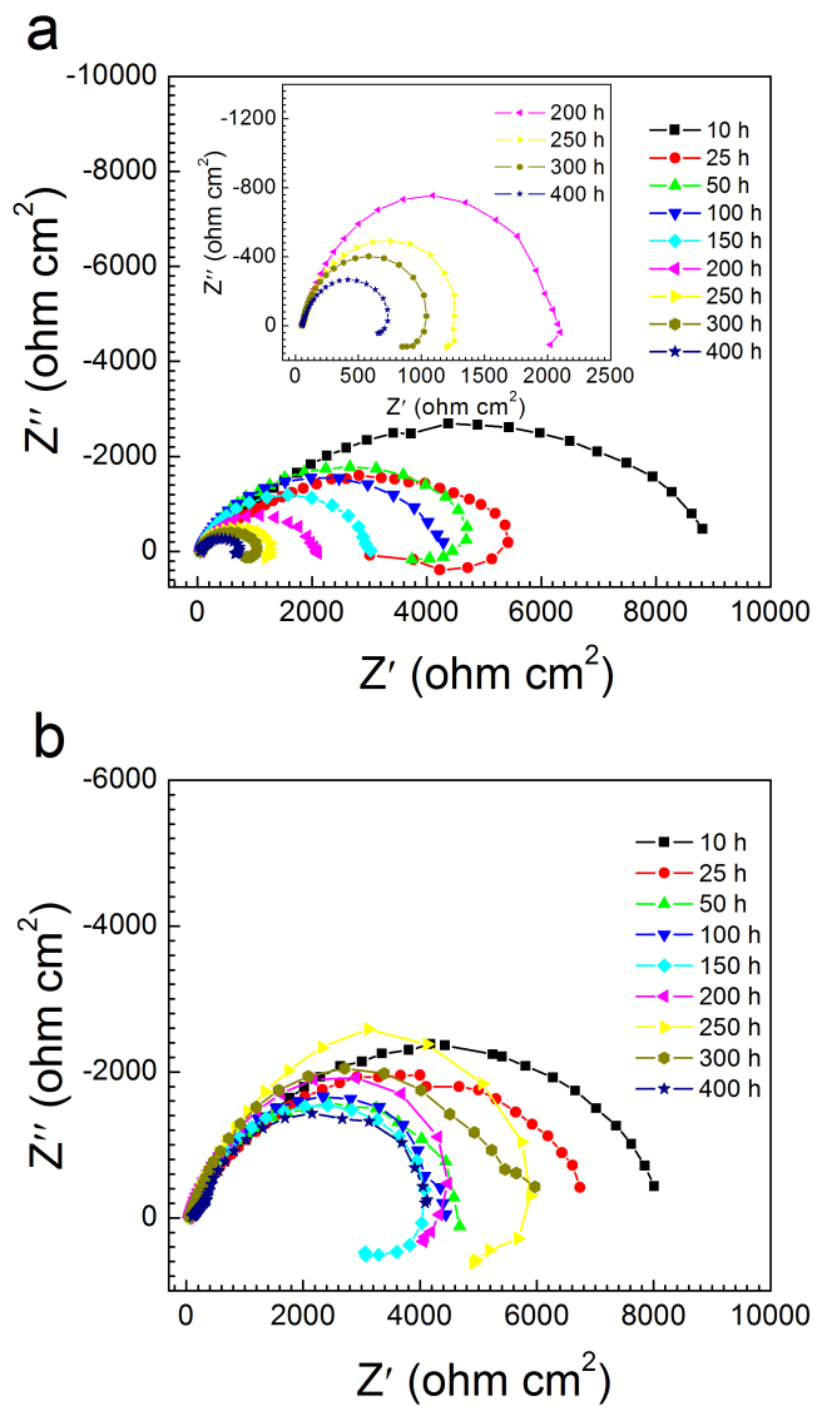

Fig. 11 


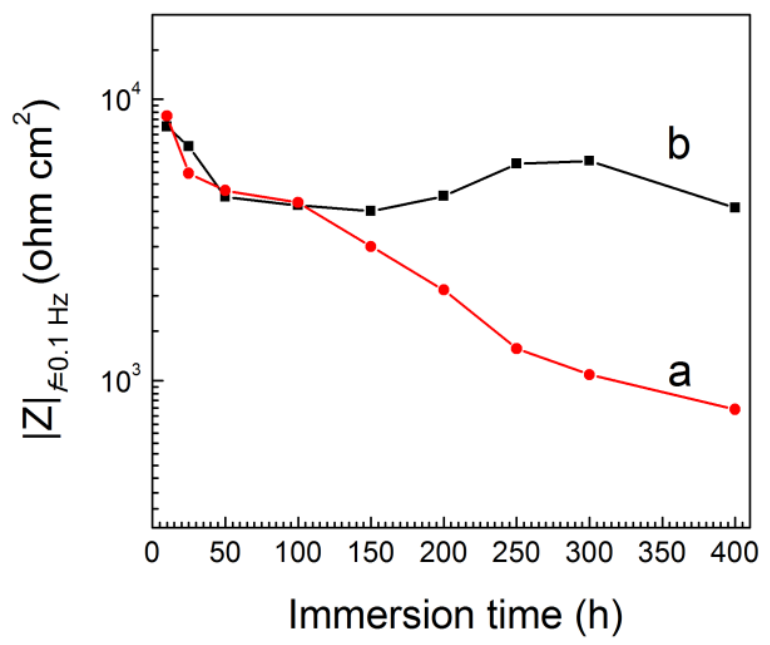

Fig. 12 


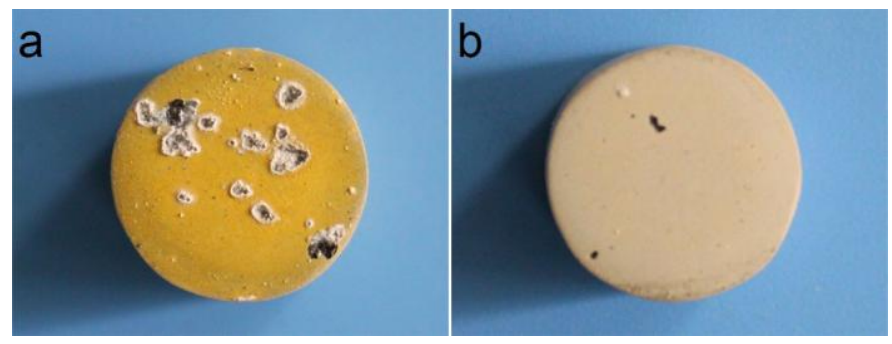

Fig. 13 
Table 1 Atomic concentration of elements in composite coating B (at.\%).

\begin{tabular}{llllllll}
\hline Composite Coating B & $\mathrm{O}$ & $\mathrm{F}$ & $\mathrm{Na}$ & $\mathrm{Mg}$ & $\mathrm{Al}$ & $\mathrm{Si}$ & $\mathrm{Sn}$ \\
\hline Region 1 & 43.21 & 0.49 & 0.81 & 34.56 & 1.32 & 18.85 & 0.77 \\
Region 2 & 48.29 & 0.99 & 0.62 & 30.06 & 1.67 & 13.72 & 4.65 \\
\hline
\end{tabular}


Table 2 Electrochemical parameters related to potentiodynamic polarization curves.

\begin{tabular}{llll}
\hline Sample & $E_{\text {corr }}(\mathrm{V} / \mathrm{SCE})$ & $i_{\text {corr }}\left(\mathrm{A} / \mathrm{cm}^{2}\right)$ & $R_{\mathrm{p}}\left(\Omega \mathrm{cm}^{2}\right)$ \\
\hline Bare Mg-Li alloy & -1.68 & $6.46 \times 10^{-4}$ & 126 \\
PEO coating & -1.43 & $2.48 \times 10^{-6}$ & 32699 \\
Composite coating A & -1.37 & $8.90 \times 10^{-7}$ & 86878 \\
Composite coating B & -1.34 & $2.94 \times 10^{-7}$ & 137183 \\
\hline
\end{tabular}


Table 3 EIS fitted results.

\begin{tabular}{llllll}
\hline Sample & $R_{\mathrm{s} 1}\left(\Omega \mathrm{cm}^{2}\right)$ & $Q_{\mathrm{b} 1}\left(\mathrm{~F} / \mathrm{cm}^{2}\right)$ & $R_{\mathrm{b} 1}\left(\Omega \mathrm{cm}^{2}\right)$ & $L\left(\mathrm{H} \mathrm{cm}^{2}\right)$ & $R_{\mathrm{L}}\left(\Omega \mathrm{cm}^{2}\right)$ \\
Mg-Li alloy & 50.24 & $1.23 \times 10^{-5}$ & 234.90 & 206.70 & 73.60 \\
\hline Sample & $R_{\mathrm{s} 2}\left(\Omega \mathrm{cm}^{2}\right)$ & $Q_{\mathrm{ou}}\left(\mathrm{F} / \mathrm{cm}^{2}\right)$ & $R_{\mathrm{ou}}\left(\Omega \mathrm{cm}^{2}\right)$ & $Q_{\mathrm{in}}\left(\mathrm{F} / \mathrm{cm}^{2}\right)$ & $R_{\mathrm{in}}\left(\Omega \mathrm{cm}^{2}\right)$ \\
PEO coating & 44.81 & $5.43 \times 10^{-7}$ & $6.02 \times 10^{3}$ & $2.35 \times 10^{-6}$ & $2.24 \times 10^{4}$ \\
Composite Coating A & 49.76 & $7.57 \times 10^{-7}$ & $1.54 \times 10^{4}$ & $1.99 \times 10^{-6}$ & $5.05 \times 10^{4}$ \\
Composite Coating B & 69.72 & $5.96 \times 10^{-7}$ & $3.21 \times 10^{4}$ & $2.49 \times 10^{-6}$ & $5.68 \times 10^{4}$ \\
\hline
\end{tabular}

